Sharon Pace

Marquette University Sharon.pace@marquette.edu

\title{
THE AKEDAH: A DIVERSE SAMPLING FROM ANTIQUITY AND THE MIDDLE AGES
}

Belief in the justice of God and in a purposeful existence guided by the Divine Presence is often belied by experience. If, on the one hand, faith teaches that life is meaningful, steered by divine personal providence, experience, on the other hand, often mocks these claims. The history of Jewish interpretation of the Akedah, or Binding of Isaac, shows that deep-seated questioning of the pillars of faith is probed and tolerated. The justice of God, the divine tolerance of suffering, the role of the patriarchs, the offering of the martyr, and the possibility of finding meaning in the absurd are all questions that emerge from an examination of the nineteen verses found in Genesis 22. In this study, I provide a sampling of the disquieting questions that emerge in Jewish reflection on the Akedah from antiquity to the Middle Ages. ${ }^{1}$ This survey shows that earlier generations' questions found various responses. In some investigations, queries were left unanswered; in other commentaries, we may find answers, but they may leave us unsatisfied. Some questions were answered in argumentation, others in story, still others were deflected. The foci are varied - once the emphasis is on God's command, alternatively, on the prompting of Satan. The hero is once Abraham, again Isaac. Ultimately, the story and its commentary reflect a powerful grip of disquietude. The silence and incompleteness of the answers are mirrored in the permutations of emphases and responses found in the totality of the tradition.

(1) The most recent comprehensive studies on the interpretations of the Akedah include: I. Kalimi, “Go, I Beg you, Take your Beloved Son and Slay Him!" The Binding of Isaac in Rabbinic Literature and Thought, Review of Rabbinic Judaism 13:1 (2010) 1-29; L. Huizenga, The New Isaac: Tradition and Intertextuality in the Gospel of Matthew (Leiden: Brill, 2009) (Supplements to Novum Testamentum, 131); E. Noort, E. TigchelaAr (eds.), The Sacrifice of Isaac: The Aqedah (Genesis 22) and its Interpretations (Leiden: Brill, 2002) (Themes in Biblical Narrative 4). These works have an extensive bibliography. 
Each generation probes the following questions that stem from the biblical account. How could an omniscient God ask such a horrific question of Abraham, seemingly negating His covenantal promise? Why command an act - child sacrifice - that God's own words forbid? The narrative warns the reader that God's directive to Abraham is only a test. But apparently Abraham does not know this - or does he? How can it be that the Abraham who pleaded for Sodom and Gomorrah does not plead for his beloved son? How could Abraham listen to this command to commit murder? Upon the completion of Abraham's act of obedience, God declares that He now knows that Abraham will totally submit to the divine will. But must an omniscient God pose such a cruel test to discover this? And for those who see Abraham as the obedient, sublime patriarch, why should he be so lauded when countless other Jews have no happy ending to their own trials of the loss of their children?

\section{GoD}

The tradition deals with the unreasonable and troubling aspects of the command in various ways. One method emphasizes that, all along, Abraham hoped that God would save Isaac; a second, that the results of Abraham's obedience were transformative, mitigating the irrationality by turning to the fruits of the results. A third protects the capriciousness of the command by deflection - the test was prompted by Satan; a fourth dares to allow the awful command to stand in its bleak severity.

\section{Hope that God would save}

One trajectory underscores that Abraham's faith was unshakeable, not only because he obeyed God's command, but because he believed that God would ultimately find another path that would redeem his son. This point stresses that behind the unfathomable, seemingly cruel demands of God lies a higher purpose that will become known in the future. Thus, in a discussion of God's test of Abraham, we find a reference to the divine loyalty to Israel - the Almighty will come through in the end, saving them as He did in the battle of Midian (Gen. Rab. 55:3). ${ }^{2}$ According to the sages, Abraham expresses this faith to Isaac, for, in commenting on the biblical verse, "we will worship and we will return to

(2) Quotations from Midrash Rabbah are taken from Midrash Rabbah, trans. H. Freedman, 10 vols. (London: Soncino, 1983). 
you," one midrash explains that Abraham "thus informed him [Isaac] that he would return safely from Mount Moriah" (Gen. Rab. 56:2). Another tradition emphasizes divine compassion, for Abraham was only able to say these words because of God's gift of prophecy. We find, for example, "Abraham was given the good tidings that Isaac would come back with him," even if he did not know the particulars (Pesiq. Rab. 40).

A distinct interpretation lessens the heartlessness of God's command by emphasizing His concomitant mercy. Indeed, God never thought Abraham would comply with the command. As we find in Tanhuma, "Even though I said to him (in Gen. 22:2): PLEASE TAKE $<$ YOUR SON $>$, it never entered my mind that he would slaughter his son" (Tanh 4.39 [S. Buber edition]). ${ }^{3}$ Reflecting on the horrors of child sacrifice, the gemara reflects on the biblical references to Mesha, Jephthah, and Abraham:

And it is further written, Which I commanded not, nor spake it, neither came it to my mind. 'Which I commanded not': This refers to the sacrifice of the son of Mesha, the king of Moab, as it is said, Then he took his eldest son that should have reigned in his stead and offered him for a burnt-offering. 'Nor spake it'; This refers to the daughter of Jephtha. 'Neither came it to my mind': This refers to the sacrifice of Isaac, the son of Abraham. (b. Ta'an. 4a. Cf. Gen. Rab. 55:5 $)^{4}$

Here, not only do the sages make clear that God neither desired the sacrifice of Mesha's son nor of Jephthah's daughter, but also that God neither desired that Abraham sacrifice Isaac nor expected him to carry out the command. Similarly, Rabbi Aha relates this account of the patriarch:

[Abraham wondered]: Surely Thou too indulgest in prevarication! Yesterday Thou saidest, For in Isaac shall seed be called to thee (Gen. XXI, 12); Thou didst then retract and say, Take now thy son (ib. XXII, 2); while now Thou biddest me, LAY NOT THY HAND UPON THE LAD! Said the Holy One, blessed be He, to him: 'O Abraham,

(3) Midrash Tanhuma, Translated into English with Introduction, Indices, and Brief Notes [S. Buber Recension], trans. J. Townsend, 2 vols. (Hoboken, NJ: Ktav, 1989).

(4) The Bible itself condemns the ancients who follow the forbidden practice of child sacrifice. See the following: Lev 20:2-5; Deut 12:29-31; 18:10; 1 Kings 16:34; 2 Kings 16:2-3; 2 Kings 17:17; 23:10; Psalms 106:37-38; Isa 57:5; Jer 7:31; 19:3-6; 32:35; Ezek 16:20; 23:37-39. 
My covenant will I not profane (Ps. LXXXIX, 35), And I will establish My covenant with Isaac (Gen. XVII, 21). When I bade thee, "Take now thy son," etc., I will not alter that which is gone out of My lips (Ps. loc. cit.). Did I tell thee, Slaughter him? No! but, "Take him up." Thou hast taken him up. Now take him down.' (Gen. Rab. 56:8.)

On the one hand, this stream of interpretation lessens the apparent capricious nature of God by showing His constancy to His commands. Technically, God never retracted His decree - because His directive never specified that Isaac be sacrificed - rather, God ordered Abraham to bring Isaac up to the mountain's summit. God's charge to take Isaac down is equally incumbent upon Abraham; indeed, when the Almighty completes this terse command, Abraham, like Job, remains silent. His questioning attitude is effectively silenced. Yet, the brevity of God's words to Abraham yet emphasizes the gulf between God's commands and human understanding. No further attempt is made in this pericope to rationalize the arbitrariness of the apparently rescindable orders.

\section{The Results of Abraham's Obedience}

One way that the unreasonableness of the command of the Almighty is mitigated is by seeing it as part of God's plan for the world..$^{5}$ Immediately before the Akedah, we see the fulfillment of the promise at least the first step of it - with the birth of Isaac and the expulsion of Hagar (Gen 21). With this test, Abraham's uprightness is proven in two ways. In one, God sees Abraham's constancy and credits it to his descendants. This righteousness is reckoned as merit to Israel in the future. In another, the world has proof why God chose Abraham and Israel for His unique mission.

\section{Credit for Descendants}

Reflecting on God's command to Abraham, R. Jonathan turns to a scriptural verse that states, "The Lord trieth the righteous" (Ps 11:5). He continues, "A potter does not examine defective vessels, because he cannot give them a single blow without breaking them. What then does he examine? Only the sound vessels, for he will not break them even with many blows. Similarly, the Holy One, blessed be He, tests

(5) The shock and unreasonableness of God's command to Abraham is all the more arresting when we remember the biblical context: multiple times he is given the promise of descendants. See Gen 12:1-3, 7; 13:14-17; 15:1-6; $17: 1-8 ; 18: 10$. 
not the wicked but the righteous..." (Gen. Rab. 55:2). The results of this testing are further explained: "So when the children of Isaac give way to transgressions and evil deeds, do Thou recollect for them the binding of their father Isaac and rise from the Throne of Judgment and betake Thee to the Throne of Mercy, and being filled with compassion for them have mercy upon them and change for them the Attribute of Justice into the Attribute of Mercy! (Lev. Rab. 29:9). ${ }^{6}$ Abraham's obedience becomes a model for faithful behavior by Jews who face trials from persecution or from life's brutal losses. If life is meaningful, purposeful, it must be connected with God's plan for Israel, even in times of trials. Thus, just as Abraham was tested by the unfathomable, so too could later generation see their torments as tests given by an inscrutable God. It appears that the sages concluded that such testing meant that the sufferers, like Abraham, should be counted among God's righteous. In such a context, we might imagine that the beleaguered would appeal to God, hoping that He would respond mercifully, as He did for the righteous Abraham.

This emphasis on the results of the test is emphasized in Rashi's commentary on the Torah. He begins by echoing the midrash: "God perplexes the righteous [at first] - and [only] afterwards reveals [his intention]. All this [is done] for the purpose of increasing their reward" (Commentary on Gen 22:2). ${ }^{7}$ Rashi likens Abraham's experience to that of Jonah, who had to act on God's directive without knowing its outcome; similarly, he compares Abraham's act of cleaving the wood to the splitting of the Jordan - a redemptive act on behalf of all Israel. Indeed, the consequences of Abraham's obedience are immeasurable and effect all generations - both those who live in the days of temple sacrifice and those beyond, because Abraham's righteousness is linked with atonement. ${ }^{8}$

Of the phrase "as it is said [to] this day," (Gen 22:14), Rashi concludes that future generations will see that the time period refers to

(6) See also Judith 8:26-27. It is interesting to note that this saying refers to "the children of Isaac" instead of "the children of Abraham," perhaps emphasizing here that not only Abraham, but also Isaac was tested.

(7) Quoted from The Metsudah Chumash/Rashi, vol. 1, Bereishis, trans. A. Davis (New York: Gross Bros., 2000).

(8) For further discussion on the connection of the Akedah and the temple, see F. Landy, The Temple in the Aqedah (Genesis 22), in: I. Kalimi, P. J. HaAs (eds.), Biblical Interpretation in Judaism and Christianity (New York: T \& T Clark, 2006) (Library of Hebrew Bible/Old Testament Studies, 439) 220-237. 
their own, one that will be marked by God's forgiveness. Rashi alludes to the significance of the Akedah for the Rosh Hashanah liturgy, because on this holiday, the narrative of the Binding of Isaac is read, the ram's horn is sounded, and the following prayer is recited: ${ }^{9}$

Remember on our behalf, O Lord our God the covenant and the love and the oath that you swore to Abraham our father on Mt. Moriah. Let it appear before you, this Akedah, that Abraham bound Isaac his son on the altar, and he suppressed his compassion in order to do your will with a complete heart. Therefore your compassion should suppress your anger against us. Through your goodness may your anger be removed from your city and your inheritance. But preserve for us what you promised in your Torah..."10

As Signer shows, this interpretation of the atoning value of Abraham's obedience grew in the history of interpretation, climaxing in a unique insight of Rashi. ${ }^{11}$ Whereas the midrash speaks of the Akedah as the equivalent of resulting in Isaac's ashes on the altar, Rashi actually visualizes the ashes. In the midrash (upon which Rashi's reflections are based) we find these words attributed to Abraham: "'Sovereign of the worlds! Regard the act as though the blood of Isaac were being sprinkled before Thee!'...He burnt the ram and said: 'O consider the act as though Isaac's ashes were being heaped up upon the altar'" (Num. Rab. 17:2). ${ }^{12}$ Numbers Rabbah shows that God indeed looked at Abraham's act as though he completed the sacrifice of his son, accepting

(9) In addition to the link with Rosh Hashanah, the Akedah is also associated with Pesach. See E. Kessler, The Sacrifice of Isaac (The Akedah) in Christian and Jewish Tradition: Artistic Representations, in: M. O'Kane (ed.), Borders, Boundaries, and the Bible (Sheffield-New York: Sheffield Academic Press, 2002) (JSPSS, 313) 86.

(10) Zichronot of Rosh Hashanah Musaf. Quoted in: J. Milgrom, The Binding of Isaac: The Akedah - A Primary Symbol in Jewish Thought and Art (Berkeley, CA: Bibal Press, 1988) 70-71. See also L. Berman, The Binding of Isaac (Northvale, NJ: Jason Aronson), 155.

(11) M. Signer, Rashi's Reading of the Akedah, The Journal of the Society for Textual Reasoning 2.1, n.p. [cited 22 December 2010]. Online: http://etext. lib.virginia.edu/journals/tr/volume2/signer.html. See also M. Bregman, Seeing with the Sages: Midrash as Visualization in the Legends of the Aqedah, in: M. L. Raphael (ed.), The Legends of the Agedah: Agendas for the Study of Midrash in the Twenty-First Century (Williamsburg, VA: The College of William and Mary, 1999) 84-100.

(12) See also Lev. Rab. 36:5, b. Ta'an. 16a, Pesiq. Rab. 40, and Tanh Vayera 23. 
Abraham's plea. Rashi continues this motif with the following: "God will see [remember] this akeidah so that He may forgive Israel every year and save them from punishment. So that it may be said 'on this day' - in all the future generations - on the mountain of God shall be seen the ashes of Yitzchok heaped and standing for the purpose of atonement" (Commentary on 22:14). Signer concludes, "[Rashi's] commentary called upon God to look upon the ashes of Isaac heaped on the altar. If the divine eye were cast upon this pile of ashes it would surely evoke mercy for Israel, the children of Abraham - who was beloved of God." ${ }^{13}$ With these compassionate words, Rashi emphasizes the continuing love of God for his long-suffering people.

In addition to the Zichronot prayer, the use of the ram's horn in the Rosh Hashanah liturgy recalls the Akedah. The shemone esrei of the Rosh Hashanah liturgy quotes this prayer from the Mishnah: "May He who answered Abraham our father on Mt. Moriah, answer you and listen to your crying voice this day" ( $m$. Ta'an. 2.4). ${ }^{14}$ This supplication finds a parallel in R. Abbahu's emphasis that the binding of Isaac is truly the binding of all Israel. He comments: "Why do we blow on a ram's horn? The Holy One, blessed be He, said: Sound before Me a ram's horn so that I may remember on your behalf the binding of Isaac the son of Abraham, and account it to you as if you had bound yourselves before $\mathrm{Me}^{\prime \prime}$ (b. Roš. Haš. 16a).

From the past answer that God gave Abraham comes the hope for the future. How did God answer Abraham? Although Abraham never actually sacrificed his son, the midrash relates that God regarded as though he did. Thus, R. Joshua reflects on this verse of Micah: "Wherewith shall I come before the Lord, and bow myself before God on high...Shall I give my firstborn for my transgression, the fruit of my body for the sin of my soul?" (Mic 6:6), concluding that it refers to God's acceptance of Abraham's offering of Isaac (Gen. Rab. 55:5). Indeed, Abraham himself appeals to God, "Sovereign of the Universe! Look upon the blood of this ram as though it were the blood of my son Isaac" (Gen. Rab. 56:9). Of this principle of merit Jo Milgrom states, "[it is the] credit card that never expires, for the faith and the trial. Whenever in the future Israel

(13) Signer, "Seeing with the Sages," n. p.

(14) Similarly, in the Talmud we find this reference in a discussion of the benedictions said when praying for deliverance from famine and pestilence: "He who answered Abraham on Mt. Moriah he shall answer you and hearken this day to the voice of your cry. Blessed art Thou O Lord who redeemest Israel" (b. Ta'an. 15a. See also $b$. Ta'an. 15b). 
is entangled... in sin, or trapped by enemies, they will sound the shofar and God will remember and save. Significantly, the atonement Isaac achieves is through his trial alone, not his death."15

Thus, within this type of interpretation, we find that Abraham's righteousness serves as a springboard for the merit of the collectivity. Abraham's act, completed once in time, has eternal significance for all his people. On that one occasion on Mount Moriah, God's command seemed unreasonable, unfathomable. But in the final analysis, its significance could only be seen in retrospect. In the future, equally unreasonably perhaps, God would forgive Israel and protect it, even when such safeguard would be unmerited. Israel will be given credit for Abraham's righteousness in face of their own trials.

\section{A testimony for the nations}

Beyond the significance for Israel, Abraham's act serves as testimony to the nations. God's apparently irrational command has a very rational purpose: to prove to the world that God's choice of Abraham and his descendants, Israel, is warranted. Rashi expands on the verse, "for now I know that you fear God, since you have not withheld your son, your only son, from me," (Gen 22:12) with these words, "For now I have a response to Satan and the nations who wonder at My love for you. I now have a justification for they see that you are God-fearing" (Commentary on 22:12). With these words, Rashi develops a more ancient tradition preserved in the midrash in which the biblical verse is interpreted as follows: "For now I know [means] I have made it known to all - that thou lovest Me." (Gen. Rab. 56:7). A variation of this theme is found in the discussion of the biblical text that precedes the Akedah, namely, the expulsion of Hagar and Ishmael. The concerns of the sages are repeated by Rashi, as well; the narrative of Gen 21 may present a false impression about Abraham to the nations - that he was cruel. Yet, upon seeing his astounding obedience, they would know that his exemplary nature was unparalleled. (Gen. Rab. 54:2.)

\section{Satan's Role}

For some interpreters, removing God one step from the initiation of the command lessens the problem of theodicy. Just as the Adversary prompts God to test the guiltless Job in the Tanak, so too does Satan

(15) Milgrom, The Binding of Isaac..., 100-101. 
repeat the attack on an innocent by challenging God to construct such a test for Abraham. With this comparison, the tradition shows sensitivity to Abraham's suffering and the concomitant inscrutability of God's demand. It protects the view of a just God by emphasizing that the prompt was something He agreed to upon Satan's instigation, thus removing Him one step from the apparent injustice. As in the book of Job, the gulf that separates the divine plan and human's capacity to understand that design is underscored.

The way in which Satan's plan is initiated stresses the sensitivity that the tradition has to the possible blemishes on the patriarchal record. The opening words of the Akedah, "After these things," prompt the exegesis that the time reference is to a dialogue that occurred between God and Satan. Satan reflects on the banquet that Abraham has to fete Isaac's circumcision. Satan chides God, remarking that Abraham neglected to offer even the humblest of sacrifices to God, esteeming his own son while slighting the Almighty (b.Sanh. 89b). In response to this taunt, God responds with the command to offer Isaac. Furthermore, Satan's role is expanded to not only distance God's direct role, but also to heighten the piety of both Abraham and Isaac by continuing his temptations to have the patriarchs disobey God. Samael (Satan) goads Abraham with these charges: he is insane, he would annihilate God's gift given at his advanced age, God would charge him with murder! Abraham's piety and innocence is underscored by the words of Job that are placed in his mouth with which he responds to these accusations: "If a thing be put to thee as a trial, wilt thou be wearied?" (Job 4:2, cited in Gen. Rab. 56:4). Having failed to weaken Abraham's spirit, Satan turns to Isaac, revealing Abraham's true intentions. Sensitive to the theological difficulties posed by the narrative, this midrash shows Isaac appealing to Abraham's compassion with the exclamation "why?" - but in the end, he is shown accepting his fate (Gen. Rab. 56:4). Even at the end of the narrative, Satan does not give up. Abraham felt he had to hide Isaac when preparing the altar lest Satan disqualify Isaac as a proper sacrifice by blemishing him with a stone (Gen. Rab. 56:5).

\section{Allow Questioning: Disqualification, Perplexity, Protest}

In one tradition, Abraham attempts to void his ability to submit to God's demand by a technical disqualification. It appears that this was an acceptable way for the sages to mark Abraham's protest. Abraham asked God whether he could indeed offer a sacrifice, since he was not 
a priest. God, however, answered him, "I have already appointed thee to be a priest," and continues, "Thou art a priest forever,"-quoting Ps 110:4 (Gen. Rab. 55:7). Pesiqta Rabbati expands as follows: Abraham states, "Master of universes, am I fit to offer Isaac up? Am I am priest? Shem is High Priest. Let him come and take Isaac from me for the offering" (Pesiq. Rab. 40). This does not deflect God's command, however, as $\mathrm{He}$ insists that He will consecrate Abraham on Moriah.

One Talmudic passage, in contrast, is willing to express consternation at Abraham's silence in response to God's command, but, at the same time, expresses perplexity that God would issue the order in the first place. In this case, although Abraham is chided, it is the king, who represents God, who beats his subjects.

Rabbi ‘̆́kiba tells of a king who had four sons. One is struck and is silent. Another is struck and is defiant. The third is struck and is suppliant. Whereas the last says to his father, "Chasten me!" Abraham is smitten and is silent. As it is written: Take now thy son, thine only son, whom thou lovest (Gen. 22:2). He could have said, "Yesterday Thou hast said to me, For in Isaac shall seed be called to thee (ibid. 21:12)." Yet he remained silent. For it is written: And Abraham rose early in the morning (ibid. 22:3). (Sem. 8.11)

In wishing that Abraham posed the question, the passage seems to ask at the same time: why was the king (God) doing the chastisement in the first place? By identifying what Abraham should have said, this context, in effect, asks why would God toy with something as essential as the covenantal promise? Why would he threaten Isaac, the only one through whom the divine promises could be manifest? By not providing an answer, the text underscores the divine inscrutability, the chasm that exists between God's plan and human understanding.

The questioning of God continues. In his examination of Gen. Rab. 55:3, Simi Peters emphasizes that the sages insist there are things humans cannot understand, yet they still allow for the scrutiny to occur. In the pericope above, the phrase, "The Lord trieth the righteous" (Ps 11:5) refers to Abraham, who is likened to the king's subject. Of the king (God), this midrash continues, one must conclude, "Forasmuch as the king's word hath power; and who may say unto him: What doest thou" (Eccl. VIII, 4)? Peters concludes that although the questioning ends with the declaration that things go beyond human comprehension, the process of examination is acceptable. The sages conclude that the faith-

(16) Milgrom, The Binding of Isaac..., 81. 
ful can question, within the context of knowing "that God is King, and that we must fear Him." ${ }^{17}$

Considering the willingness of the sages to pose unanswerable queries regarding the Akedah, Milgrom demonstrates how, through clever paranomasia, R. Hiyya displays this dichotomy: From Moriah can come either instruction or fear (horah'ah vs. yir'ah); light or fear-awe ('ora vs. mora'); commandment or plague (dibber vs. debher); Moriah can be described as either a mountain of myrrh/incense (mor) or a place that issues bitterness (mara) (Gen. Rab. 55:7). She concludes, "Moriah is not all roses and dedication... R. Hiyya... sees the dark side. The word play will work for him too in raising the specter of the misuses of religious dedication, the savagery of power, its waste of life, the seeming irreversible preconditions of our existence."18

Another way to press the apparent capriciousness of God's revocation of the command was to continue the questioning dialogue that Abraham had with God. In one midrash, upon hearing the negation of the command, Abraham laments to the Almighty that when he first received the directive, he could have argued that God was rescinding His promise that the covenant would be continued through Isaac. Yet, Abraham protests, "I did not do this, but suppressed my feelings of compassion in order to do Thy will" (Gen. Rab. 56:10). He goes one step further, intimating that indeed he has endured enough. In an impassioned voice, Abraham dares to say to God: "Swear to me not to try me again henceforth, nor my son Isaac" (Gen. Rab. 56:11). In Pesiqta Rabbati, Abraham capitalizes on God's silence in response to his protest, audaciously giving God a directive! Not only will the pain he endured by keeping silent reap benefits for his own future, sparing him from similar agony, but he insists that his suffering will do the same for his descendants:

...My answer could have been this: "Yesterday, Thou didst tell me, In Isaac shall seed be called to Thee (Gen 21:12), and now Thou commandest me to cut Isaac's throat!" But I did not voice this answer. Instead I acted like a man who is dumb or one who is deaf... Now each year on this day, when Isaac's children are called to account before Thee, no matter how many accusers bring charges against them, do Thou listen in silence and give no heed to the accusers, just as I kept silent and gave Thee no answer. (Pesiq. Rab. 40:6)

(17) S. Peters, Learning to Read Midrash (Jerusalem: Urim Publications, 2004) $88-89$.

(18) Milgrom, The Binding of Isaac..., 121-22. 
It is extraordinary that Abraham's demand does not end simply with its articulation. Rather, God not only answers, but tolerates further pressing by Abraham, as we find in the following text: "In reply to Abraham's prayer the Holy One, blessed be He, said: 'Yes, I shall take note of what happened on this day'" (Pesiq. Rab. 40:6). Still, Abraham presses on with this insistence: "Swear unto me." Pesiqta Rabbati relates that God accedes to Abraham's demand: "And God swore at once: By Myself have I sworn, saith the Lord (Gen 22:16)." Thus, the Bible's declaration that He has evidence of Abraham's loyalty becomes God's promise to use this loyalty to protect future generations of Jews, identified as "Isaac's children" (Pesiq. Rab. 40:6). Abraham's obedience will serve to protect Israel from limitless future sin or never-ending future attack. Abraham's children become, in effect, Isaac's children, for although it is Abraham's obedience that God noted, here it is the near-sacrifice of the victim that has the same atoning value as if he were immolated.

Finally, we note the unique interpretation cited by Menahem Kasher in his anthology on Gen 22:8, from a manuscript of 'Abot de Rabbi Nathan. Although Isaac consented to God's will, alternative feelings are nonetheless expressed: "Isaac, indeed, consented with his lips at that moment, but in his heart he prayed, 'Oh that I may be saved from my father's hand. I have no other helper but the Holy One, blessed is He,' as it says, My help comes from the Lord, who made heaven and earth (Ps. 121:2)". As Milgrom notes, this text "give[s] evidence of Isaac's resistance." Isaac actually expresses his dismay at what Abraham is about to do! This reflects a very different approach than the one usually taken: that Isaac was the perfect victim, willing and obedient (as we discuss below). ${ }^{19}$

\section{Further Significance of Moriah}

\section{Sacrifice}

In the history of interpretation, the atoning value of the Akedah we discussed above is no surprise, as it is correlated with the very essence of Moriah. This location is linked with the quintessential place

(19) M. Kasher, The Encyclopedia of Biblical Interpretation [Torah Shelemah]: A Millennial Anthology, trans. H. Freedman. Genesis: vol. 3 (New York: American Biblical Encyclopedia Society, 1957) 144. Another English translation of this midrash is given in Milgrom, The Binding of Isaac..., 81, based on M. KasHER, Torah Shelemah [Hebrew], vol. 3, t. 4 (New York: American Biblical Encyclopedia Society, 1949) 882. 
of atonement via sacrifice, the locus in the material world in which humankind can obtain a glimpse of the transcendent world and God's forgiveness. It is the place of past sacrifice as well as the future location of the temple. Even before Abraham, Moriah was a place of sacrifice because here, Adam, Cain and Abel, and Noah offered sacrifice. The acts of Adam and Noah are linked to that of Abraham because they share something essential: they all participate in the bridge that God has given humanity to connect with the divine on Mount Moriah for forgiveness. In the days of the temple period, sacrifice linked Israel with the God. Thus, in the Tanak we find: "Solomon began to build the house of the Lord in Jerusalem on Mount Moriah, where the Lord had appeared to his father David, at the place that David had designated, on the threshing-floor of Ornan the Jebusite" (2 Chron 3:1). The roots of this link are found in the Akedah itself, as sacrifice and worship are intertwined with the very creation of the world. In discussing the reason why God spared Isaac, Rabbi Isaac made the following associations: "Everything happened as a reward for worshipping. Abraham returned in peace [accompanied by Isaac] from Mt. Moriah only as a reward for worshipping... The Torah was given only as a reward for worshipping... The Temple was built only as a reward for worshipping... The dead will come to life again only as a reward for worshipping" (Gen. Rab. 56:2). Indeed, Geza Vermes notes that all atoning sacrifices are linked to the Akedah. ${ }^{20}$ The following quotation from the Fragmentary Targum regarding the tamid (daily offering) is telling: "The lamb was chosen to recall the merit of the lamb of Abraham, who bound himself on the altar and stretched out his neck for Your Name's sake. Heaven was let down and descended and Isaac saw its perfection and his eyes were weakened by the high places. For this reason he acquired merit and a lamb was provided there, in his stead, for the burnt offering." 21

In the future, Moriah will be linked with God's "attempts" to bring a righteous humanity into the world. Targum Pseudo-Jonathan refers to these stages: "And they came to the place of which the Lord had told him. And Abraham builded there the altar which Adam had built, which had been destroyed by the waters of the deluge, which Noah

(20) See discussion in G. Vermes, Scripture and Tradition in Judaism: Haggadic Studies (Leiden: Brill, 1961) (Studia Post-Biblica, 4) 208-212.

(21) Quoted in Vermes, Scripture and Tradition in Judaism..., 211. See also Lev. Rab. 2:11. 
has again builded, and which had been destroyed in the age of divisions [the time of the tower of Babel]; and he set the wood in order upon it, and bound Izhak his son, and laid him on the altar upon the wood" (Tg. Ps.-J., commentary on Gen 22. Cf. Song Rab. 4:6, 2). ${ }^{22}$ In other words, with Adam, with Noah, at Babel, and with Abraham, God offered humanity consecutive chances to live according to His design.

Furthering the transcendent significance of Moriah, we find that this mountain is connected with the other symbolic mountains of spiritual significance in Israel: both Sinai - the mountain on which the torah was given - and Zion - the mountain on which torah will go forth. The connection of all three is found in this example: "He took the measure of all the mountains and found no mountain other than Mount Sinai suitable for giving the torah on it. He took the measure of all lands and found no city other than Jerusalem suitable for building the Temple within it. Again the Holy One, blessed be He, took the measure of all the mountains and found no mountain other than Mount Moriah upon which He might cause His presence to dwell" (Pesiq. Rab. 50). Another midrash preserves the same correlation of Moriah and Zion, with the following links made in the name of R. Yannai and R. Hiyya respectively: "[Moriah] is the place whence reverence (mora') and awe (yir'ah) came forth into the world," and "[Moriah] is the land whence instruction (hora'ah) came forth: For out of Zion shall come forth the law, and the word of the Lord from Jerusalem (Isa. 2:3)" (Pesiq. Rab. 40:6). Further, the very existence of Moriah points to the resurrection, for in the context of discussing the significance of worship on Moriah, one midrash states, "The dead will come to life again only as a reward for worshipping (Gen. Rab. 56:2). ${ }^{23}$

(22) For discussion on the links between the Akedah and sacrifice see G. Wenham, The Akedah: A Paradigm of Sacrifice, in: D. Wright, D. N. Freedman, A. Hurvitz (eds.), Pomegranates and Golden Bells: Studies in Biblical, Jewish, and Near Eastern Ritual, Law, and Literature in Honor of Jacob Milgrom (Winona Lake, IN: Eisenbrauns, 1995) 93-102.

(23) The transcendent connections between these mountains have early roots. Thus, we find in Jub. 18:13, "And Abraham called that place 'the Lord has seen,' so that it is said 'in the mountain the Lord has seen.' It is Mount Zion." Because of their spiritual connection, such links are easily made. See Huizenga, The New Isaac..., 83. Similarly, Josephus shows this connection. See Ant. 1.222-227. 


\section{Earthy Sustenance}

Not only does Moriah provide Israel a connection with God via sacrifice, it also allows for their earthy sustenance and survival - it provides food. We note the following discussion: "AND HE TOOK IN HIS HAND THE FIRE AND THE KNIFE (MA'AKELETH). R. Hanina said: Why is a knife called ma'akeleth? Because it makes food (oklim) fit to be eaten. While the rabbis said: all eating (akiloth) which Israel enjoy in this world, they enjoy only in the merit of that MA'AKELETH (KNIFE)" (Gen. Rab. 56:3). The words ma'akeleth, oklim and akiloth are all derivatives of the same root ' $k l$. Milgrom comments: The principle that certain miracles happened to Israel because of the merit of the Akedah is thus extended here to encompass Israel's basic physical survival." ${ }^{24}$ Similarly, we note the expansion on this theme in Midrash Tanhuma, which states that the reason the word ma'akhelet was chosen for "knife," as opposed to sakin, is because Israel was provided abundant nourishment under God's providence (Tanh 4.46).

\section{IsAAC'S ELEVATION}

With the trajectory that stresses the atoning value of Abraham's act, another branch is developed; some interpretations shift the focus to Isaac, the consummate willing victim. On the one hand, there is a tradition which underscores the human side of Isaac. On the other hand, more emphasis is placed on his spiritual elevation. Except for one altercation with Ishmael, Isaac is at once the knowing, obedient victim, the resurrected soul, or a participant in the angelic realm.

\section{Isaac: human}

As the Akedah begins with the phrase, "after these things," commentators reflected on the antecedents to the event. In the Bible, the previous narrative recounts the expulsion of Hagar and Ishmael, prompted by Sarah's concerns regarding any connection between Ishmael and Isaac. Thus, one midrash speaks of a specific confrontation that occurred between Ishmael and Isaac. Isaac responds to Ishmael's taunts that the latter's circumcision is more noteworthy than his own by bragging that he would sacrifice other limbs of his body. Upon Ishmael's boast that he is more virtuous than Isaac on account of his own circumcision at an older age, Isaac responds, "On account of one limb

(24) Milgrom, The Binding of Isaac..., 133. 
wouldst thou incense me! ...were the Holy One, blessed be He, to say unto me, Sacrifice thyself before Me, I would obey" (Sanh. 89b). But any hubris is quickly overshadowed by the interpretations that underscore Isaac's perception as he looks toward Moriah and his faithful participation in Abraham's lead. ${ }^{25}$

\section{Isaac's Spiritual heights}

Isaac's spiritual insight is stressed when, early in the journey, Abraham asks his son to consider Mount Moriah in the distance. Unlike the two servants who accompany father and son, Isaac sees a pillar of fire on Mount Moriah, stretching to the heavens. Abraham understands Isaac's observation as a sign of his worthiness as a perfect sacrifice (Pirqe R. El. 31). In addition, when Isaac discovers Abraham's intentions, the interpretations by far emphasize his absolute willingness. For example, when Isaac expressed his puzzlement regarding the absence of a sacrificial animal, Abraham replies, "God will provide himself the lamb, $\mathrm{O}$ my son; and if not, Thou art for a burnt-offering, my son" (Gen. Rab. 56:4). Despite this horrific comment, father and son continued together, "one to slaughter and the other to be slaughtered" (Gen. Rab. 56:4). Similarly, we find: "Isaac was not distressed by what his father had said to him. Even as the one rejoiced to make the offering, the other rejoiced to be made an offering of" (Pesiq. Rab. 40). Moreover, Isaac is shown as being particularly careful that nothing be done to disqualify him as an offering. He begs his father to bind him tightly, lest he flinch, causing a blemish - a technical cause for disqualification (Pesiq. Rab. 40; Gen. Rab. 56:8). ${ }^{26}$

In an interesting variation of the specifics of Isaac's concern, we find that in Pirqe Rabbi Eliezer 31, Isaac is afraid not of physical disqualification, but of breaking one of the ten commandments, which, he reasons, would also disqualify him. Fearing that he would curse his father upon experiencing fear of dying, he begs to be bound tightly lest he break the commandment of honoring one's father: "O my father! Bind for me my two hands, and my two feet, so that I do not curse thee: for instance a word may issue from the mouth because of the violence and dread of death, and I shall be found to have slighted the precept, "Honour thy father" (Pirqe R. El. 31).

(25) See also Gen. Rab. 55:4.

(26) This theme is also present in 4Q225. See the discussion in HuIzenga, The New Isaac..., 88-93. 
In another example of Isaac's piety while bound on the altar, it is he - and not Abraham - who sees the angels who observe the Akedah: "Abraham's eyes were scanning the eyes of Isaac, and <Isaac's> eyes were scanning the angels of the heights; Isaac saw them, Abraham did not see them..." (Frg. Tg. 22.10). Thus, the prospective victim is, in effect, praised by the tradition for his duty-bound fealty to both his father and to God.

\section{ISAAC: PARADIGMATIC MARTYR}

\section{Inspiration for martyrdom}

For modern readers, one of the most troubling aspects of the interpretive history of the Akedah is the connection made between this text and the experiences of those who faced the unfathomable loss of their children due to martyrdom. Both Abraham and Isaac are held up as paragons: one is willing to obey God even when it means the annihilation of all that is dear, and one is willing to offer himself as the consummate victim. Yet, the fact remains: the trial found in Gen 22 does not end in death. God only tested Abraham and Isaac. God used their obedience and willingness - as developed in the history of tradition - to educate the world and to atone for Israel. How then can the Akedah be meaningful to those who witnessed such horrible occasions with no deliverance? Even in antiquity, authors dared to ask this question, finding solace with the paradigm of Abraham's trial and Isaac's submission. Early examples come from 2 and 4 Maccabees, in which we find the arresting accounts of Eleazar and that of the mother and her seven sons.

On one level, martyrs are held up as models of virtue: "All people, even their torturers, marveled at their courage and endurance, and they became the cause of the downfall of tyranny over their nation. By their endurance they conquered the tyrant, and thus their native land was purified through them" (4 Macc 1:11). In addition, as shown by the faithfulness and prayer of one individual, Eleazar, we find that martyrdom effects atonement. While dying at the hands of his tormentors, he speaks for all martyrs: "Be merciful to your people, and let our punishment suffice for them. Make my blood their purification, and take my life in exchange for theirs" (4 Macc 6:28-29).

Another well-known martyr story that is found in various settings is the account of the mother and her seven sons. Found first in 2 Maccabees and 4 Maccabees, she finds courage and inspiration from the 
heritage of the Akedah to endure the brutality and torture of Antiochus. In rabbinic writings, her story is told in a new second century C.E. setting, during the time period of Roman persecution in the aftermath of the Bar Kokhba rebellion (b. Git. 57b; Lam. Rab. 1:16, 50). From the narrative's earliest form in the books of Maccabees, we find that martyrdom accounts and the hope for resurrection are linked, as shown in the mother's words to her children, "Therefore the Creator of the world, who shaped the beginning of humankind and devised the origin of all things, will in his mercy give life and breath back to you again, since you now forget yourselves for the sake of his laws" (2 Macc 7:23). ${ }^{27}$ Similarly, she appeals to her family's reunification after death, telling her youngest, "Do not fear this butcher, but prove worthy of your brothers. Accept death, so that in God's mercy I may get you back again along with your brothers" (2 Macc 7:27). ${ }^{28}$ In the version told in the midrash, the mother's forceful words express her great faith, yet reveal her audacity, saying her good-bye to her last child with these words: "My son, go to the patriarch Abraham and tell him, "Thus said my mother, "Do not preen yourself [on your righteousness], saying I built an altar and offered up my son, Isaac." Behold, our mother built seven altars and offered up seven sons in one day. Yours was only a test, but mine was in earnest.'"' ${ }^{29}$ These traditions of the mother and seven sons show that the Akedah was paradigmatic. Abraham's and Isaac's behavior was seen as inspirational in later generations who faced state sanctioned persecution and torture. With her own comparison to Abraham provided by the mother, however, one tradition dared to highlight the abyss of loss that contrasted with the divine intervention that Abraham and Isaac received.

For such martyrs who suffered under the tyranny of Antiochus, the model of their ancestors Abraham and Isaac becomes, both terribly and grippingly, true: "Remember that it is through God that you have had a share in the world and have enjoyed life, and therefore you ought to endure any suffering for the sake of God. For his sake also our father Abraham was zealous to sacrifice his son Isaac, the ancestor of our nation; and when Isaac saw his father's hand wielding a knife and descending upon him, he did not cower" (4 Macc 16:18-20). Both Abraham's submission and Isaac's willingness is cited, showing

(27) Cf. the words of the fourth son on resurrection in 2 Macc 7:13-14.

(28) See, also, the comparison of the mother to Abraham in 4 Macc 14:20.

(29) Similarly, b. Git. 57b. 
that the increased emphasis on Isaac, compared to the biblical text, occurred before the turn of the eras: "'Brothers, let us die like brothers for the sake of the law... Remember whence you came, and the father by whose hand Isaac would have submitted to being slain for the sake of religion'" (4 Macc 13:9-12). These traditions share one presupposition: a tenacious belief in the unseen, a steadfast confidence in a seemingly unjustifiable hope.

\section{Hope for the Resurrection and the Coming of Messiah}

\section{Resurrection}

Ultimately these exegetical traditions which emphasize the relevance of the Akedah to actual martyrdom trust that, in the world to come, wrongs will be righted and that the God who sees all will reward the just. We find the following extraordinary reference to resurrection that is seen to be linked with the Akedah.

When the blade touched his neck, the soul of Isaac fled and departed, (but) when he heard His voice from between the two Cherubim, saying (to Abraham), "Lay not thy hand upon the lad" (Gen. xxii. 12), his soul returned to his body, and (Abraham) set him free, and Isaac stood upon his feet. And Isaac knew that in this manner the dead in the future will be quickened. He opened (his mouth), and said: Blessed art thou, O Lord, who quickeneth the dead." Pirqe R. El. 30 [31 English] ${ }^{30}$

Similarly, Abraham is included with the blessing of an eternal reward in the world to come: In the same context we find this promise to Abraham - that he will receive his reward both in this world, with a multitude of descendants, and "in the world to come" (Pirqe R. El. 31). ${ }^{31}$

W. J. Van Bekkum illustrates how the gulf between Isaac's potential martyrdom and the tragedy of actual death could be crossed..$^{32}$ In his

(30) This blessing comprises the second of the 18 benedictions of the shemoneh esrei.

(31) For further study, see J. Levenson, The Death and Resurrection of the Beloved Son: The Transformation of Child Sacrifice in Judaism and Christianity (New Haven: Yale University Press, 1993).

(32) W. J. Van Beккum, The Aqedah and its Interpretations in Midrash and Piyyut, in: E. Noort, E. TigchelaAr (eds.), The Sacrifice of Isaac: The Agedah (Genesis 22) and its Interpretations (Leiden: Brill, 2002) (Themes in Biblical Narrative: Jewish and Christian Traditions, 4) 86-95. The reference cited above is 
study of the poetry of Ephraim ben Jacob of Bonn (1133-1221) who lived during the Second Crusade's persecution of Jews, he relates this remarkable selection from Ben Jacob's writings: "They [the Bonn Jewish Community] offered up sacrifices: they prepared victims like Isaac their father". ${ }^{33}$ For this medieval community the analogy sorrowfully worked, because, according to this interpretation, indeed, Isaac did die on Mount Moriah. The resurrection that God granted the obedient, willing Isaac, yet awaited their own children. With this faith, they might derive a modicum of solace in their horrific circumstances.

\section{Coming of the Messiah}

In much of Jewish interpretation, the justice of God and the transformation of the world's sorrows act as paradigms for the future. Thus, the Akedah is associated with the ultimate hope for the transformation of the world - the coming of the messiah, which is connected with the timeless significance of Abraham's act. We note the following text: "The ashes of the ram were the base which was upon the top of the inner altar. The sinews of the ram were the strings of the harp whereon David played. The ram's skin was the girdle (around) the loins of Elijah... The horn of the ram... (was the one) wherein He blew upon Mount Sinai... [and] is destined in the future to be sounded in the world that is to come" (Pirqe R. El. 31). Here, the effects of the Akedah accompanied Israel at the giving of the torah, with the covenant with David, and will be present with Elijah, the prophet who heralds the messiah; further its transformative effects will continue to occur in the world to come. In addition, as the coming of the messiah is linked to the resurrection, it is also often specified that the dead will be raised at the time of the final redemption. Indeed, a remarkable interpretation of the Akedah claims that Isaac was resurrected on Mount Moriah, a preview of the ultimate resurrection in days to come: "Isaac purified himself and in intention offered himself up to God, was at that moment etherealized, and, as it were, he ascended to the throne of God like the odour of the incense of spices which the priests offered before Him twice a day; and so the sacrifice was complete" (Zohar 120b).

In this context of the Zohar, God's compassionate purposes for Israel supersede any doubt or despair that grips Abraham, for at the mo-

from H.-G. von Mutius, Ephraim von Bonn, Hymnen und Gebete (Hildesheim: Georg Olms Verlag, 1989) (Judaistische Texte und Studien, 11) 84-90.

(33) Van Bеккuм, The Aqedah and its Interpretations..., 92-93. 
ment of his questioning, Abraham beheld the ram made at the twilight of creation. So essential was this substitute for God's ultimate design that the Zohar continues that the ram "was pre-ordained... at the moment when Abraham should require it." In other words, as were all the items made "at twilight," the substitutionary ram "was predestined to appear at the requisite moment" (Zohar 120b). The text continues, God did this because "from that time is was pre-ordained that that ram should be at hand at the moment when Abraham should require it... [as were the other things created at the twilight of creation] they were predestined to appear at the requisite moment" (Zohar 120b). ${ }^{34}$

For all the disparate strands of interpretation, we find that none became completely satisfying. No single approach dominates in the tradition. This multiplicity points to the complexity of theological responses that exist in the wake of this perennially troubling text. Thus, for all the anguish and searching in antiquity as interpreters considered God's terrible command, and for all the reflection and proposed solutions, one thing remains in common with us today - the troubling questions and mystification continue. ${ }^{35}$ While it is true that interpretations which find meaning or hope dominate, the very existence of daring, questioning texts remind us that in our own deeply skeptical age, we find a common link with those of earlier generations, who dared to challenge God's design for Mount Moriah.

\section{SUMMARY}

The diverse approaches found in the history of Jewish interpretation of the Akedah are suggestive of the theological difficulties generated by this text. Questions about the inscrutable nature of God's command to Abraham prompted reflections on the merits of the patriarch, his son Isaac, and the entire people of Israel.

(34) See the discussion in H. Schwartz, Tree of Souls: The Mythology of Judaism (Oxford: Oxford University Press, 2004) 150; m. 'Abot 5:6; b. Pesah 54a.

(35) For further study, see the following: L. JACOBS, The Problem of the Akedah in Jewish Thought, in: R. L. Perkins (ed.), Kierkegaard's Fear and Trembling: Critical Appraisals (Tuscaloosa, AL: University of Alabama Press, 1981) 1-9; M. Rosenak, The Akedah - and What to Remember, in: M. Coogan, B. EIchler, J. Tigay (eds.), Tehillah le-Moshe: Biblical and Judaic Studies in Honor of Moshe Greenberg (Winona Lake, IN: Eisenbrauns, 1997) 307-313; J. (Yehuda) GelLMAN, The Meaning of the Aqedah [Binding of Isaac] for Jewish Spirituality, in: L. J. Greenspoon, R. A. Simkins (eds.), Spiritual Dimensions of Judaism (Omaha: Creighton University Press, 2003) (Studies in Jewish Civilization, 13) 31-44. 